\title{
PENGARUH KEPEMIMPINAN TRANSFORMASIONAL DAN KEPUASAN KERJA TERHADAP PERILAKU KEWARGAAN ORGANISASI GURU SEKOLAH DASAR NEGERI KECAMATAN KRAS KABUPATEN KEDIRI
}

\author{
Imam Gunawan \\ Jurusan Administrasi Pendidikan Fakultas Ilmu Pendidikan \\ Universitas Negeri Malang
}

\begin{abstract}
The objective of this research is to found out the influence of transformational leadership and job satisfaction toward organizational citizenship behavior of the teacher in primary school Kras District of Kediri. This research used quantitative approach. The participants of the research are 159 teachers of 30 primary school Kras, District of Kediri. The data found using closed model questionnaire instrument. The data analyzed using path analyzing, with the help of SPSS PASW Statistics 18 program. The results of the research show that there is a significance influence between transformational leadership and job satisfaction toward organizational citizenship behavior of the teacher in primary school Kras, District of Kediri. The transformational leadership contributes $15.1 \%$ while the job satisfaction contribution is $20.4 \%$. Other variables beyond this research contribute $64.5 \%$.
\end{abstract}

Keywords: transformational leadership, job satisfaction, organizational citizenship behavior

\begin{abstract}
Abstrak
Tujuan penelitian ini adalah untuk mengetahui pengaruh kepemimpinan transformasional dan kepuasan kerja terhadap perilaku kewargaan organisasi guru SDN Kecamatan Kras Kabupaten Kediri. Penelitian ini menggunakan pendekatan kuantitatif. Responden penelitian sebanyak 159 orang guru di 30 SDN Kecamatan Kras Kabupaten Kediri. Data penelitian diperoleh dengan menggunakan instrumen angket model tertutup. Analisis data yang digunakan adalah analisis jalur, dengan bantuan program SPSS PASW Statistics 18. Hasil penelitian menunjukkan bahwa terdapat pengaruh yang signifikan kepemimpinan transformasional dan kepuasan kerja terhadap perilaku kewargaan organisasi guru SDN Kecamatan Kras Kabupaten Kediri. Besarnya sumbangan efektif variabel kepemimpinan transformasional adalah $15,1 \%$ dan sumbangan efektif variabel kepuasan kerja adalah $20,4 \%$ terhadap perilaku kewargaan organisasi guru, dan variabel lain yang memengaruhi perilaku kewargaan organisasi guru di luar penelitian sebesar 64,5\%.
\end{abstract}

Kata kunci: kepemimpinan transformasional, kepuasan kerja, perilaku kewargaan organisasi

A. Pendahuluan 
kepemimpinan pada bidang lainnya, namun yang membedakan ialah bidang kerjanya dan tujuannya. Kepemimpinan pendidikan dilakukan pada lembaga pendidikan, dengan tujuan memengaruhi semua warga sekolah melaksanakan tugas dan pekerjaannya dengan baik dan benar sesuai dengan tanggung jawab masing-masing, yang pada akhirnya bertujuan untuk mengembangkan segenap potensi yang dimiliki oleh peserta didik. Kepemimpinan berlaku di semua bidang organisasi, tak terkecuali bidang pendidikan. Kusmintardjo (1989: 256) menyatakan kepemimpinan pendidikan adalah kepemimpinan yang berlangsung di dalam situasi atau lingkungan pendidikan, yang berarti bahwa kepemimpinan pendidikan hendaknya menampilkan ciri-ciri kepemimpinan yang bersifat mendidik.

Kepemimpinan pendidikan sebagai satu kemampuan dan proses memengaruhi, mengkoordi nasi, dan menggerakkan orang atau kelompok lain yang ada hubungan nya dengan pengembangan ilmu pengetahuan dan pelaksanaan pendidikan dan pengajaran, agar kegiatan-kegiatan yang dijalankan dapat lebih efektif dan efisien di dalam mencapai tujuan-tujuan pendidikan dan pengajaran. Hal ini dipertegas oleh Dirawat yang mengemukakan bahwa kata pendidikan di belakang kata kepemimpinan hendaknya menampakkan pula sifat-sifat atau ciri-ciri khusus kepemimpinan yang bersifat mendidik dan mengemong, bukan memaksa atau menekan dalam bentuk apapun (Kusmintardjo, 1989: 256). Kepemimpinan pendidikan adalah tindakan atau perilaku di antara individuindividu dan kelompok-kelompok yang menyebabkan mereka bergerak ke arah tercapainya tujuan-tujuan pendidikan. Berdasarkan uraian tersebut dapat disimpulkan kepemimpinan pendidikan adalah segenap kegiatan yang berupaya memengaruhi orang lain, baik perorangan maupun sekelompok orang, di lingkungan atau situasi pendidikan agar mereka bersedia dan ikhlas secara sukarela bersama-sama mencapai tujuan-tujuan pendidikan yang telah ditetapkan.

Pendekatan kepemimpinan transformasional awalnya digagas oleh James MacGregor Burns. Burns (1978) membedakan dua jenis kepemimpinan yaitu: (1) kepemimpinan transaksional; dan (2) kepemimpinan transformasional. Pemimpin bercorak transaksional adalah mereka yang memimpin lewat pertukaran sosial, misalnya politisi memimpin dengan cara menukar satu hal dengan hal lain, seperti pekerjaan dengan suara atau subsidi dengan kontribusi kampanye, dan pemimpin bisnis bercorak transaksional menawarkan financial reward bagi produktivitas atau tidak memberi reward atas kurangnya produktivitas. Burns (1978) mengemukakan bahwa transformational leadership is a process in which leaders and followers raise to 
higher levels of morality and motivation. Gaya kepemimpinan semacam ini akan mampu membawa kesadaran para pengikut (followers) dengan memunculkan ide-ide produktif, hubungan yang sinergikal, kebertanggungjawaban, kepedulian, dan cita-cita bersama.

Pemimpin dengan

kepemimpinan transformasional adalah kepemimpinan yang memiliki visi ke depan dan mampu mengidentifikasi perubahan lingkungan serta mampu mentransformasi perubahan tersebut ke dalam organisasi, mempelopori perubahan dan memberikan motivasi dan inspirasi kepada individu-individu karyawan untuk kreatif dan inovatif, serta membangun team work yang solid, membawa pembaharuan dalam etos kerja dan kinerja manajemen, dan bertanggung jawab memimpin dan mengendalikan organisasi (Bass, 1985). Hal ini dipertegas oleh Yulk (2009) yang berpendapat bahwa esensi kepemimpinan transformasional adalah memberdayakan para pengikutnya untuk berkinerja secara efektif dengan membangun komitmen mereka terhadap nilai-nilai baru, mengembangkan keterampilan dan kepercayaan mereka, menciptakan iklim yang kondusif bagi berkembangnya inovasi dan kreativitas. Pemimpin organisasi dalam merumuskan perubahan biasanya menggunakan pendekatan transformasional yang manusiawi, di mana lingkungan kerja yang partisipatif dengan model manajemen yang kolegial, keterbukaan, dan keputusan diambil bersama.

Kepemimpinan transformasional adalah kepemimpinan yang mampu menciptakan perubahan yang mendasar dan dilandasi oleh nilai-nilai budaya untuk menciptakan inovasi dan kreativitas pengikutnya dalam rangka mencapai visi yang telah ditetapkan. Pemimpin transformasional sesungguhnya merupakan agen perubahan, karena memang erat kaitannya dengan transformasi yang terjadi dalam suatu organisasi. Fungsi utamanya adalah berperan sebagai katalis

perubahan, bukan sebagai pengontrol perubahan. Seorang pemimpin transformasional memiliki visi yang jelas, memiliki gambaran holistik tentang bagaimana organisasi di masa depan ketika semua tujuan atau sasaran telah tercapai. Seorang pemimpin transformasional adalah seorang pemimpin yang mempunyai keahlian diagnosis dan selalu meluangkan waktu dan mencurahkan perhatian dalam upaya untuk memecahkan masalah dari berbagai aspek.

Pemimpin

bercorak transformasional adalah mereka yang merangsang dan menginspirasi pengikutnya, baik untuk mencapai sesuatu yang tidak biasa dan dalam prosesnya, serta mengembangkan kapasitas kepemimpinannya sendiri. Pemimpin transformasi onal membantu pengikutnya untuk berkembang dan 
membuat mereka jadi pemimpin baru dengan cara merespons kebutuhan-kebutuhan yang bersifat individual dari para pengikut. Mereka memberdayakan para pengikut dengan cara menyelaraskan tujuan yang lebih besar individual para pengikut, pemimpin, kelompok, dan organisasi. Pemimpin transformasional adalah pemimpin yang dapat memindahkan (transformasi) nilai, idealisme, perilaku, mental, dan sikap yang baik kepada bawahan. Hal ini dipertegas oleh Boje (2000) yang berpendapat bahwa pemimpin transaksional akan bekerja dalam budaya organisasi yang sudah ada, sedangkan pemimpin transformasional akan mengubah budaya organisasi.

Davis dan Newstroom (2002) mengemukakan bahwa job satisfaction is the favorableness or unfavorableness with employees view their work. Kepuasan kerja berarti perasaan mendukung atau tidak mendukung yang dialami (pegawai) dalam bekerja. Sementara itu Wexley dan Yukl (1977) mengartikan kepuasan kerja sebagai the way an employee feels about his or her job. Kepuasan kerja adalah cara pegawai merasakan dirinya atau pekerjaannya. Berdasarkan uraian tersebut dapat disimpulkan bahwa kepuasan kerja adalah perasaan yang menyokong atau tidak menyokong dalam diri pegawai yang berhubungan dengan pekerjaan maupun kondisi dirinya. Perasaan yang berhubungan dengan pekerjaan melibatkan aspek-aspek seperti upaya, kesempatan pengembangan karier, hubungan dengan pegawai lain, penempatan kerja, dan struktur organisasi. Sementara itu, perasaan yang berhubungan dengan dirinya antara lain berupa umur, kondisi kesehatan, kemampuan, dan pendidikan. Handoko (1999) menyatakan kepuasan kerja adalah keadaan emosional yang menyenangkan dengan mana para karyawan memandang pekerjaan mereka. Kepuasan kerja mencerminkan perasaan seseorang terhadap pekerjaannya. Hal ini merupakan dampak dari sikap positif karyawan terhadap pekerjaan dan segala sesuatu yang dihadapi di lingkungan kerjanya.

Robbins (2003) menyatakan kepuasan itu terjadi apabila kebutuhankebutuhan individu sudah terpenuhi dan terkait dengan derajat kesukaan dan ketidaksukaan dikaitkan dengan pegawai. Kepuasan kerja merupakan sikap umum yang dimiliki oleh pegawai yang erat kaitannya dengan imbalanimbalan yang mereka yakini akan mereka terima setelah melakukan sebuah pengorbanan. Apabila memerhatikan pendapat Robbins, maka terkandung dua dimensi, yaitu: (1) kepuasan yang dirasakan individu yang titik beratnya individu anggota masyarakat; dan (2) kepuasan yang merupakan sikap umum yang dimiliki oleh pegawai. Kepuasan kerja menunjukkan sikap umum seorang 
individu terhadap pekerjaannya. Seseorang dengan sikap kepuasan tinggi menunjukkan sikap yang positif terhadap kerja, sebaliknya seseorang yang tidak puas terhadap pekerjaannya menunjukkan sikap yang negatif terhadap pekerjaan tersebut (Robbins, 2003). Kepuasan kerja yang tinggi menandakan bahwa sebuah organisasi sekolah telah dikelola dengan baik dengan manajemen yang efektif. Kepuasan kerja merupakan perasaan dan perilaku individu berkenaan dengan pekerjaannnya. Semua aspek dari pekerjaan yang baik maupun buruk, positif, maupun negatif akan berperan menciptkan perasaan kepuasan ini.

Hasibuan

mendefinisikan kepuasan kerja adalah sikap emosional yang menyenangkan dan mencintai pekerjaannya. Sikap ini dicerminkan oleh moral kerja, kedisiplinan, dan prestasi kerja. Ada perbedaan yang penting antara perasaan ini dan unsur lainnya dari sikap pegawai. Kepuasan kerja adalah perasaan senang atau tidak senang yang relatif berbeda dari pemikiran objektif dan keinginan perilaku. Kepuasan kerja adalah suatu keadaan emosional guru di mana terjadi atau tidak terjadi titik temu antara batas jasa guru dan tingkat nilai balas jasa, baik finansial maupun non finansial. Sehingga dapat disimpulkan kepuasan kerja adalah tingkat di mana seseorang merasa positif atau negatif tentang berbagai segi dari pekerjaan, tempat kerja, dan hubungan dengan teman kerja. Berdasarkan paparan di atas dapat diidentifikasi jenisjenis sasaran yang harus dicapai sebelum kepuasan kerja dapat diperoleh, yaitu: (1) uang; (2) wibawa; (3) kedudukan; (4) keamanan; (5) pengakuan; (6) rasa memiliki; dan (7) kreativitas.

Organ (1988) mengemukakan perilaku kewargaan organisasi (organizational citizenship behavior / OCB) merupakan perilaku individu yang ekstra, yang tidak secara langsung atau eksplisit dapat dikenali dalam suatu sistem kerja yang formal, dan yang secara agregat mampu meningkatkan keefektifan fungsi organisasi. Organisasi pada umumnya percaya bahwa untuk mencapai keunggulan harus mengusahakan kinerja individual yang setinggi-tingginya, karena pada dasarnya kinerja individual memengaruhi kinerja tim atau kelompok kerja dan pada akhirnya memengaruhi kinerja organisasi secara keseluruhan. Kinerja yang baik menuntut perilaku sesuai guru yang diharapkan oleh organisasi sekolah. Perilaku yang menjadi tuntutan organisasi saat ini adalah tidak hanya perilaku in-role, tetapi juga perilaku extra-role. Perilaku extra-role ini disebut juga dengan perilaku kewargaan organisasi.

Perilaku kewargaan organisasi guru merupakan istilah yang digunakan untuk mengidentifikasikan perilaku guru sehingga dia dapat disebut sebagai anggota yang baik. Perilaku ini cenderung melihat seseorang (guru) 
sebagai makhluk sosial (menjadi anggota organisasi), dibandingkan sebagai makhluk individual yang mementingkan diri sendiri. Sebagai makhluk sosial, manusia mempunyai kemampuan untuk memiliki empati kepada orang lain dan lingkungannya dan menyelaraskan nilai-nilai yang dianutnya. Nilai-nilai yang dimiliki lingkungannya digunakan untuk menjaga dan meningkatkan interaksi sosial yang lebih baik. Terlebih lagi, untuk melakukan segala sesuatu yang baik, manusia tidak selalu digerakkan oleh hal-hal yang menguntungkan dirinya, misalnya seseorang mau membantu orang lain jika ada imbalan tertentu.

Jika guru dalam organisasi sekolah memiliki perilaku kewargaan organisasi, maka usaha untuk mengendalikan guru dapat menurun, karena guru dapat mengendalikan perilakunya sendiri atau mampu memilih perilaku terbaik untuk kepentingan organisasinya. Borman dan Motowidlo (1993) menyatakan bahwa perilaku kewargaan organisasi dapat meningkatkan kinerja organisasi (organizational performance), karena perilaku ini merupakan pelumas dari mesin sosial dalam organisasi, dengan kata lain dengan adanya perilaku ini, interaksi sosial pada anggotaanggota organisasi menjadi lancar, mengurangi terjadinya perselisihan, dan meningkatkan efisiensi. Perilaku ini muncul karena perasaan sebagai anggota organisasi dan merasa puas apabila dapat melakukan suatu yang lebih kepada organisasi. Perasaan sebagai anggota dan puas bila melakukan suatu yang lebih hanya terjadi jika guru memiliki persepsi yang positif terhadap organisasinya. Sloat mengemukakan bahwa perasaan sebagai bagian anggota organisasi dan kepuasan, akan terjadi jika anggota memiliki persepsi yang positif terhadap organisasi (Diah, dkk., 2014:281).

Hal ini dipertegas oleh Organ (1988) yang menyatakan perilaku kewargaan organisasi dianggap memberikan kontribusi terhadap kesejahteraan komunitasnya, transformasi sumber daya, peningkatan inovasi dan daya adaptasi serta kinerja organisasi secara keseluruhan termasuk peningkatan efektivitas dan efisiensi pengerahan sumber daya, waktu dan pemecahan masalah di antara unit-unit kerja dengan cara kolektif dan interdependensi. Sehingga dapat disimpulkan bahwa perilaku kewargaan organisasi diasumsikan dapat memengaruhi kinerja organisasi secara keseluruhan, termasuk meningkatkan keefektifan dan efisiensi pengerahan sumber daya, waktu, dan penyelesaian masalah di antara unit-unit kerja dengan cara kolektif dan interdependensi. Jika memerhatikan paparan tersebut, dapat diketahui bahwa perilaku kewargaan organisasi diasumsikan memengaruhi keputusan kompensasi, promosi, dan pelatihan serta memiliki efek yang penting terhadap kinerja keuangan suatu organisasi. Lebih 
lanjut Organ (1988) menyatakan bahwa perilaku kewargaan organisasi akan menerangkan proporsi halo effect dalam penilaian kinerja dan merupakan determinan bagi program manajemen sumber daya manusia dalam mengawasi, memelihara, dan meningkatkan sikap kerja yang akumulasinya akan berpengaruh pada kesehatan psikologi, produktivitas, dan daya pikir pekerja.

Perilaku tersebut tidak akan mendapat imbalan langsung atau sanksi, baik dilakukan atau tidak, namun sikap konstruktif yang ditunjukkan pegawai melalui perilaku kewargaan organisasi akan memberikan penilaian positif atasan, seperti penugasan dan promosi. Eisenberger mengungkap kan bahwa perilaku ini berkembang sejalan dengan seberapa besar perhatian organisasi pada tingkat kesejahteraan guru dan penghargaan organisasi terhadap kontribusi mereka (LaMastro, 1999). Persepsi guru yang baik terhadap dukungan organisasional kepada kualitas kehidupan kerja mereka akan menimbulkan rasa "hutang budi" dalam diri mereka pada organisasi sehingga mereka akan merasa memiliki kewajiban untuk membayarnya. Kualitas interaksi atasan-bawahan juga diyakini sebagai prediktor perilaku kewargaan organisasi. Interaksi atasan-bawahan yang berkualitas tinggi akan memberikan dampak seperti meningkatnya kepuasan kerja, produktifitas, dan kinerja guru. Riggio (2003) menyatakan bahwa apabila interaksi atasan-bawahan berkualitas tinggi maka seorang atasan akan berpandangan positif terhadap bawahannya sehingga bawahannya akan merasakan bahwa atasannya banyak memberikan dukungan dan motivasi. Hal ini meningkatkan rasa percaya dan hormat bawahan pada atasannya sehingga mereka termotivasi untuk melakukan lebih dari yang diharapkan oleh atasan mereka. Setelah Organ (1988) mengintroduksi perilaku kewargaan organisasi, dampak yang nyata adalah adanya gelombang perubahan besar dalam bidang perilaku organisasi. Konsep ini mengarahkan organisasi menjadi lebih inovatif, fleksibel, produktif, dan responsif.

Dimensi yang paling sering digunakan untuk mengkonseptualisasi perilaku kewargaan organisasi adalah lima dimensi yang dikembangkan oleh Organ (1988). Lima dimensi perilaku kewargaan organisasi yang dikembangkan oleh Organ (1988) yaitu: (1) altruism adalah perilaku yang merupakan pilihan personal karyawan, yang berpengaruh untuk membantu orang lain dalam menyelesaikan masalah organisasi dimana karyawan tersebut bernaung; conscientiousness adalah perilaku yang merupakan pilihan personal karyawan, yang melebihi tuntutan peran minimal dari organisasi pada area kehadiran, kepatuhan terhadap aturan dan sistem yang berlaku, pemanfaatan waktu istirahat, dan lain sebagainya; (3) sportmanship adalah 
kesediaan karyawan untuk mentolerir dan tidak mengeluhkan kondisi organisasi yang tidak sesuai dengan kondisi ideal yang diharapkan; (4) courtesy adalah bagian perilaku yang merupakan pilihan personal individu, yang bertujuan untuk mencegah munculnya masalah-masalah pekerjaan yang terkait dengan rekan sekerja; dan (5) civic virtue merupakan bagian perilaku individu yang mengindikasikan tanggung jawabnya untuk melibatkan diri atau memperhatikan keberlangsungan perusahaan.

Sementara itu Podsakoff, dkk., (1997) mengemukakan perilaku kewargaan organisasi dipengaruhi oleh empat faktor, yaitu: (1) karakteristik tugas; (2) karakteristik organisasi;

karakteristik pribadi; dan

perilaku dari pemimpin. Sedangkan

Prihatsanti dan Dewi (2010) menyatakan faktor lain yang dianggap memengaruhi perilaku kewargaan organisasi adalah kepribadian, keadilan organisasi, kepuasan kerja, komitmen terhadap organisasi serta dukungan dari tempat bekerja. Hal ini dipertegas oleh Dyne yang berpendapat bahwa faktor yang mempengaruhi perilaku kewargaan organisasi adalah sikap kerja, cyinism, nilai-nilai di organisasi, karakteristik pekerjaan, jabatan bekerja dan lama bekerja (Teresa dan Suyasa, 2008).

\section{B. Metode Penelitian}

Penelitian ini menggunakan pendekatan kuantitatif, sebab sesuai dengan tujuan penelitian yaitu untuk mengetahui pengaruh kepemimpinan transformasional dan kepuasan kerja terhadap perilaku kewargaan organisasi guru Sekolah Dasar Negeri Kecamatan Kras Kabupaten Kediri. Penelitian ini menggunakan metode korelasional, dengan tujuan untuk mengetahui hubungan tiga variabel yang dapat diukur secara kuantitatif. Dengan kata lain menyelidiki seberapa variasi dalam suatu variabel berhubungan dengan variasi dari

variabel lain berdasarkan koefisien korelasi. Wiyono (2004:24) mengemukakan bahwa koefisien korelasi yang diperoleh menunjukkan derajat kekuatan hubungan antara dua variabel yang diteliti. Adapun model rancangan dalam penelitian ini seperti dalam Gambar 1.

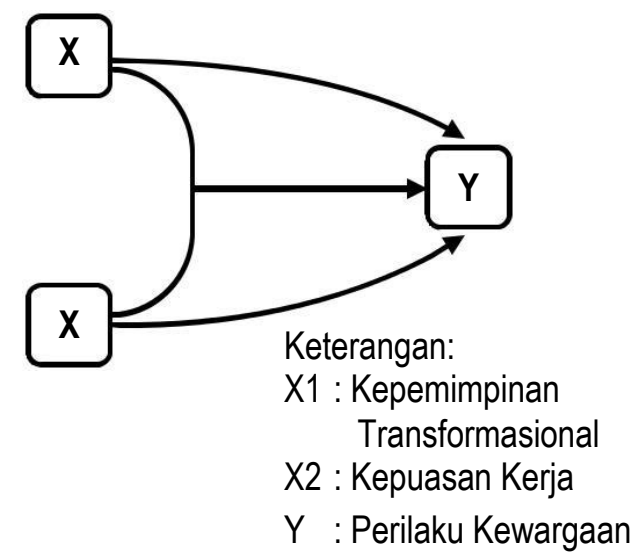

Gambar 1 Rancangan Penelitian

Populasi merupakan keseluruhan objek atau subjek sumber informasi yang diteliti. Populasi menurut Wiyono (2004:29) dapat berupa orang, benda, 
tumbuhan, peristiwa, dan gejala yang memiliki ciri-ciri tertentu dan jelas. Populasi penelitian lebih ditekankan pada jumlah keseluruhan suatu objek yang akan diteliti. Penelitian ini melibatkan populasi yang berasal dari guru SDN Kecamatan Kras Kabupaten Kediri. Jumlah guru ialah 264 orang yang tersebar di 30 SDN Kecamatan Kras Kabupaten Kediri. Teknik pengambilan sampel yang digunakan adalah proportional random sampling. Winarsunu menyatakan bahwa proportional random sampling digunakan karena karakteristik populasi terdiri dari kategori, kelompok, atau golongan yang setara atau sejajar yang diduga kuat berpengaruh pada hasil penelitian. Penentuan jumlah sampel dengan menggunakan Tabel Krejcie dan Morgan. Jumlah populasi dan sampel penelitian ditampilkan pada Tabel 1 .

Tabel 1 Jumlah Populasi dan Sampel

\begin{tabular}{|c|c|c|c|}
\hline No & Nama Sekolah & $\begin{array}{c}\text { Jumlah Populasi } \\
\text { Guru }\end{array}$ & $\begin{array}{c}\text { Jumlah Sampel } \\
\text { Guru }\end{array}$ \\
\hline 1 & SDN Kras 1 & 10 orang & 10 orang \\
\hline 2 & SDN Kras 2 & 4 orang & 4 orang \\
\hline 3 & SDN Jambean 1 & 6 orang & 6 orang \\
\hline 4 & SDN Jambean 2 & 5 orang & 5 orang \\
\hline 5 & SDN Jambean 3 & 4 orang & 4 orang \\
\hline 6 & SDN Butuh 1 & 5 orang & 5 orang \\
\hline 7 & SDN Butuh 2 & 4 orang & 4 orang \\
\hline 8 & SDN Mojosari 1 & 4 orang & 4 orang \\
\hline 9 & SDN Mojosari 2 & 4 orang & 4 orang \\
\hline 10 & SDN Pelas 1 & 4 orang & 4 orang \\
\hline 11 & SDN Pelas 2 & 5 orang & 5 orang \\
\hline 12 & SDN Rejomulyo 1 & 5 orang & 5 orang \\
\hline 13 & SDN Rejomulya 2 & 5 orang & 5 orang \\
\hline 14 & SDN Banjaranyar 1 & 5 orang & 5 orang \\
\hline 15 & SDN Banjaranyar 2 & 8 orang & 8 orang \\
\hline 16 & SDN Krandang 1 & 5 orang & 5 orang \\
\hline 17 & SDN Krandang 2 & 5 orang & 5 orang \\
\hline 18 & SDN Bendosari 1 & 5 orang & 5 orang \\
\hline 19 & SDN Bendosari 2 & 5 orang & 5 orang \\
\hline 20 & SDN Jabang 1 & 7 orang & 7 orang \\
\hline 21 & SDN Jabang 2 & 5 orang & 5 orang \\
\hline 22 & SDN Nyawangan 1 & 6 orang & 6 orang \\
\hline 23 & SDN Nyawangan 2 & 6 orang & 6 orang \\
\hline
\end{tabular}




\begin{tabular}{cccc}
\hline No & Nama Sekolah & $\begin{array}{c}\text { Jumlah Populasi } \\
\text { Guru }\end{array}$ & $\begin{array}{c}\text { Jumlah Sampel } \\
\text { Guru }\end{array}$ \\
\hline 24 & SDN Purwodadi 1 & 7 orang & 7 orang \\
\hline 25 & SDN Purwodadi 2 & 6 orang & 6 orang \\
\hline 26 & SDN Karangtalun 1 & 5 orang & 5 orang \\
\hline 27 & SDN Karangtalun 2 & 5 orang & 5 orang \\
\hline 28 & SDN Setonorejo 1 & 5 orang & 5 orang \\
\hline 29 & SDN Setonorejo 2 & 5 orang & 5 orang \\
\hline 30 & SDN Bleber & 4 orang & 4 orang \\
\hline & Total & 264 orang & $\mathbf{1 5 9}$ orang \\
\hline
\end{tabular}

Pengambilan data menggunakan pendekatan crosssectional, yakni pengambilan data dilakukan secara serentak dalam waktu yang bersamaan pada subjek yang berbeda dengan cara menyebarkan angket (Arikunto, 2010). Teknik penggalian data penelitian ini adalah dengan menggunakan teknik angket. Angket adalah salah satu teknik pengumpulan data yang dapat digunakan dalam penelitian untuk memperoleh data suatu informasi dengan cara mengajukan serangkaian pertanyaan secara tertulis, sehingga diperoleh informasi yang lebih luas dan mendalam dari responden. Angket yang digunakan adalah angket tertutup. Angket tertutup menurut Wiyono (2004:37) adalah angket yang disusun dengan menyediakan pilihan jawaban lengkap, sehingga pengisi tinggal memberi tanda pada jawaban yang dipilih. Instrumen angket disusun berdasarkan jabaran variabel, subvariabel, dan indikator. Berdasarkan indikator dijabarkan menjadi butir-butir pertanyaan dalam angket.

Analisis dari penelitian ini menggunakan analisis jalur (path analysis) dengan dasar koefisian beta dari hasil analisis regresi. Analisis jalur digunakan untuk menemukan penjelasan mengenai pola-pola hubungan langsung dan tidak langsung dari suatu model kausal yang disusun berdasarkan pertimbanganpertimbangan teoritis dan pengetahuan peneliti (Winarsunu, 2002:279). Alasan penelitian ini menggunakan analisis jalur adalah secara teoritik variabel $\mathrm{X} 1$ kedudukannya tidak sejajar dengan X2, variabel X1 menunjukkan hubungan yang bersifat recursive terhadap variabel $\mathrm{X} 2$ dan $\mathrm{Y}$, dan hubungan variabel bebas terhadap variabel terikat cenderung linear. Sebelum melakukan analisis jalur terlebih dahulu harus dilakukan uji asumsi data. Hal tersebut dilakukan dengan menguji normalitas, independensi, homogenitas, dan linieritas data penelitian.

Analisis jalur digunakan untuk mengetahui hubungan variabel 
independen bebas yang satu dengan variabel independen yang lain hingga hubungan dengan variabel dependen. Adapaun variabel independennya adalah kepemimpinan transformasional (X1) dan kepuasan kerja (X2), variabel dependennya adalah perilaku kewargaan organisasi guru (Y). Untuk mengetahui hubungan antara variabel independen dengan variabel independen yang lain hingga variabel dependen digunakan persamaan matematika pemilihan struktur sebagai berikut:

\section{Struktur I}

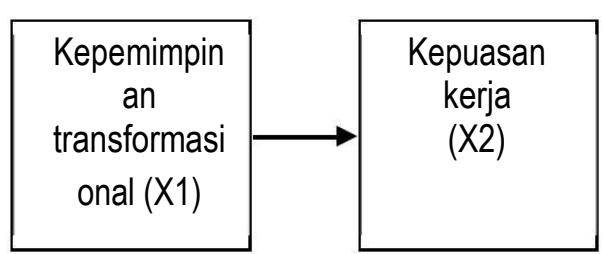

\section{Struktur II}

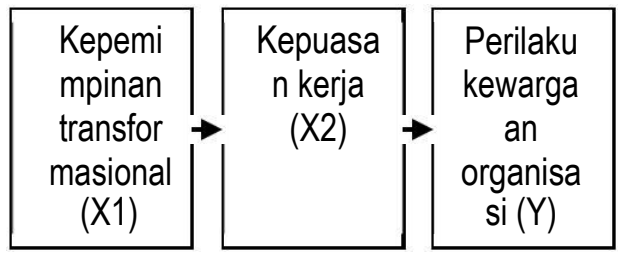

Adapun persamaan

matematikanya sebagai berikut:

Struktur I

$$
\mathrm{X}_{2}=p_{21} \mathrm{X}_{1}+p_{2 \mathrm{v}} \mathrm{V}
$$

Struktur II

$\mathrm{Y}=p_{\mathrm{y} 1} \mathrm{X}_{1}+p_{\mathrm{y} 2} \mathrm{X}_{2}+p_{\mathrm{yw}} \mathrm{W}$

(Winarsunu, 2002:288).

Perhitungan dalam analisis jalur dalam penelitian ini diselesaikan melalui analisis regresi dengan menemukan koefisien korelasi dan koefisien beta.
Analisis regresi struktur pertama digunakan untuk menemukan koefisien beta dari hubungan variabel kepemimpinan transformasional (X1) dengan variabel kepuasan kerja (X2) dengan rumus sebagai berikut:

$\mathrm{X}_{2}=\beta_{0}+\beta_{1} \mathrm{X}_{1}+\varepsilon$

Keterangan:

$\mathrm{X}_{2} \quad=$ kriterium (endogen),

$\beta_{0}=$ bilangan kostanta (beta 0$), \beta_{1}=$ bilangan konstanta (beta $\left.\mathrm{X}_{1}\right), \mathrm{X}_{1}=$ bilangan prediktor (eksogen), $\varepsilon \quad=$ error (Winarsunu, 2002:288).

Sedangkan analisis regresi terstruktur kedua digunakan untuk menemukan koefisien beta dari hubungan variabel kepemimpinan transformasional (X1) dan variabel kepuasan kerja (X2) dengan variabel perilaku kewargaan organisasi guru (Y) melalui rumus sebagai berikut:

$\mathrm{Y}=\beta_{0}+\beta_{1} \mathrm{X}_{1}+\beta_{2} \mathrm{X}_{2}+\varepsilon$

Keterangan:

$\mathrm{Y} \quad=$ kriterium,

$\beta_{0} \quad=$ bilangan konstanta (beta 0 ),

$\beta_{1}=$ bilangan konstanta $\mathrm{X}_{1}$ (beta $\left.\mathrm{X}_{1}\right), \mathrm{X}_{1}$

$=$ bilangan prediktor (eksogen), $\beta_{2}=$ bilangan konstanta $\mathrm{X}_{2}$ (beta $\mathrm{X}_{2}$ ), $\mathrm{X}_{2}=$ bilangan prediktor (endogen), $\varepsilon=$ error (Draper dan Smith, 1998:252).

Selanjutnya untuk menyajikan hasil perhitungan dilakukan langkahlangkah kerja manual (Riduwan dan Kuncoro, 2007:116-118) sebagai berikut: 
1. Menyusun tabel ringkasan koefisien jalur dari hasil proses analisis regresi tiap struktur yang berisi koefisien beta, indeks determinasi $\left(\mathrm{R}^{2}\right)$ dan indeks error $\left(1-\mathrm{R}^{2}\right)$.

2. Menyusun tabel ringkasan signifikansi masing-masing koefisien jalur (beta). Uji signifikansi dengan menggunakan uji t. Bilamana jalur yang dimaksud tidak signifikan, maka dalam model empirik variabel tersebut tidak ada hubungannya. Koefisien beta dikatakan signifikan bilamana nilai signifikansi tnya dengan $\alpha \leq 0,05$.

3. Menyusun model empirik dengan mencantumkan koefisien masing-masing jalur pada tempatnya berikut koefisien error ( $(\varepsilon)$ masingmasing.

4. Menyusun tabel ringkasan koefisien hubungan langsung dan tidak langsung. Dalam hal ini koefisien beta yang digunakan sebagai indikator hubungan langsung, sedangkan indikator hubungan tidak langsung dihitung dari mengalikan koefisien jalur yang menjadi perantara (intervening variable) menuju variabel $\mathrm{Y}$ yang selanjutnya dihitung koefisien totalnya.

5. Menginterpretasikan hubungan-hubungan variabel yang terdapat dalam tabel hubungan langsung dan tidak langsung. Bilamana koefisien hubungan langsung lebih besar dari koefisen hubungan melalui perantara maka jalur tersebut merupakan jalur yang baik. Akan tetapi bukan berarti koefisien jalur hubungan yang melalui perantara tidak baik, karena hal ini terkait dengan rekomendasi penelitian. Sebaliknya bilamana koefisien jalur hubungan yang melalui perantara lebih besar dari koefisien jalur langsung, maka jalur perantara itulah yang terbaik, dan bukan berarti jalur langsungnya tidak baik.

6. Menghitung indeks determinasi masing-masing variabel dengan rumus $\left(\beta_{i}\right)$ (rxiy).

7. Menginterpretasikan hasil perhitungan indeks determinasi masing-masing variabel untuk menjelaskan kontribusi variabel yang dimaksud terhadap variabel $\mathrm{Y}$.

\section{Hasil Penelitian}

Tujuan utama penelitian ini adalah untuk mengetahui pengaruh kepemimpinan transformasional dan kepuasan kerja terhadap perilaku kewargaan organisasi guru SDN Kecamatan Kras Kabupaten Kediri. Analisis jalur digunakan untuk menemukan penjelasan mengenai polapola hubungan langsung dan tidak langsung dari suatu model kausal yang disusun berdasarkan pertimbangan teoritis. Analisis jalur digunakan untuk mengetahui hubungan variabel eksogen (independen/ bebas) yang satu dengan 
variabel eksogen (independen/ bebas) yang lain hingga hubungan dengan variabel endogen (dependen/ terikat). Variabel eksogen dalam penelitian ini adalah kepemimpinan transformasional (X1) dan kepuasan kerja (X2), dan variabel endogen adalah perilaku kewargaan organisasi guru (Y). Berikut ini disajikan output hasil analisis regresi variabel penelitian dengan bantuan program SPSS PASW Statistics 18.

\section{Regression (X1 - Y)}

\begin{tabular}{|l|l|l|l|}
\hline \multicolumn{5}{|c|}{ Varlables Entered/Removed $^{\text {b }}$} \\
\hline Model & $\begin{array}{c}\text { Variables } \\
\text { Entered }\end{array}$ & $\begin{array}{c}\text { Variables } \\
\text { Removed }\end{array}$ & Method \\
\hline 1 & $\mathrm{X} 1^{\text {a }}$ &. & Enter \\
\hline
\end{tabular}

a. All requested variables entered.

b. Dependent Variable: $Y$

Mode I Summary

\begin{tabular}{|l|l|r|r|r|}
\hline Model & Model Summary \\
\hline 1 & $.497^{\mathrm{a}}$ & R Square & $\begin{array}{c}\text { Adjusted R } \\
\text { Square }\end{array}$ & $\begin{array}{c}\text { Std. Error of } \\
\text { the Estimate }\end{array}$ \\
\hline
\end{tabular}

a. Predictors: (Constant), $\mathrm{X} 1$

\begin{tabular}{|c|c|c|c|c|c|c|}
\hline \multicolumn{7}{|c|}{ ANOVAA } \\
\hline \multicolumn{2}{|c|}{ Model } & $\begin{array}{l}\text { Sum of } \\
\text { Squares }\end{array}$ & $d f$ & Mean Square & $F$ & Slg. \\
\hline \multirow[t]{3}{*}{1} & Regrosslon & 5609,677 & 1 & $\begin{array}{l}5009,677 \\
\end{array}$ & 51,476 & $.000^{\mathrm{a}}$ \\
\hline & Resldual & 17109,392 & 157 & 108.977 & & \\
\hline & Total & 22719,069 & 158 & & & \\
\hline
\end{tabular}
b. Dependent Variable: $Y$

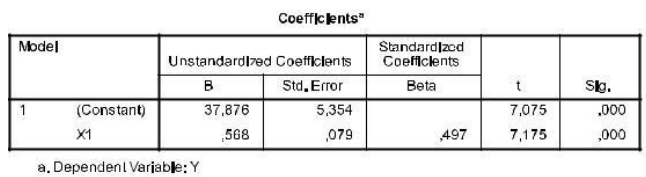

Regression (X1 - X2)
Variables Entered/Removed ${ }^{b}$

\begin{tabular}{|l|l|l|l|}
\hline Model & \multicolumn{1}{|l|}{$\begin{array}{c}\text { Variables } \\
\text { Entered }\end{array}$} & $\begin{array}{c}\text { Variables } \\
\text { Removed }\end{array}$ & Method \\
\hline 1 & $\mathrm{X} 1^{\mathrm{a}}$ & - & Enter \\
\hline
\end{tabular}

a. All requested variables entered.

b. Dependent Variable: X2

\begin{tabular}{|l|l|r|r|r|}
\multicolumn{7}{|c|}{ Model Summary } \\
\hline Model & $\mathrm{R}$ & R Square & $\begin{array}{c}\text { Adjusted R } \\
\text { Square }\end{array}$ & $\begin{array}{c}\text { Std. Error of } \\
\text { the Es timate }\end{array}$ \\
\hline 1 & $.506^{\mathrm{a}}$ & 257 &, 252 & 9,701 \\
\hline
\end{tabular}

a. Predictors: (Constant), X1

\begin{tabular}{|c|c|c|c|c|c|c|}
\hline \multicolumn{7}{|c|}{ ANOVA' } \\
\hline Mod & & $\begin{array}{l}\text { Sum of } \\
\text { Squares }\end{array}$ & $d f$ & Mean Square & $\mathrm{F}$ & Skg. \\
\hline \multirow[t]{3}{*}{1} & Regression & 5097,765 & 1 & 5097,765 & 54,167 & $.000^{8}$ \\
\hline & Resldual & 14775,606 & 157 & 94,112 & & \\
\hline & Total & 19873,371 & 158 & & & \\
\hline
\end{tabular}

. Predictors: (Constant), X1

b. Dependent Variable: $x 2$

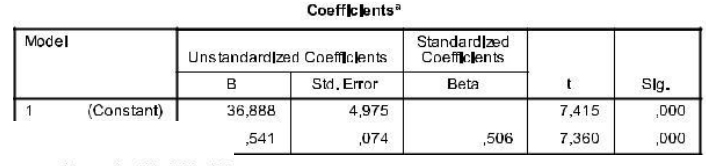

a. Dependent Variable: X2

\section{Regression (X2 - Y)}

Variables Entered/Removed ${ }^{\text {b }}$

\begin{tabular}{|l|l|l|l|}
\hline Model & \multicolumn{1}{|c|}{$\begin{array}{c}\text { Variables } \\
\text { Entered }\end{array}$} & $\begin{array}{c}\text { Variables } \\
\text { Removed }\end{array}$ & Method \\
\hline 1 & $\mathrm{X} 2^{\mathrm{a}}$ &. & Enter \\
\hline
\end{tabular}

a. All requested variables entered.

b. Dependent Variable: $Y$

\begin{tabular}{|l|l|r|r|r|}
\multicolumn{7}{|c|}{ Model Summary } \\
\hline Model & $\mathrm{R}$ & R Square & $\begin{array}{c}\text { Adjusted R } \\
\text { Square }\end{array}$ & $\begin{array}{c}\text { Std. Error of } \\
\text { the Estimate }\end{array}$ \\
\hline 1 &, $535^{\circ}$ &, 287 &, 282 & 10,161 \\
\hline
\end{tabular}

a. Predictors: (Constant), X2

\begin{tabular}{|c|c|c|c|c|c|c|}
\hline \multicolumn{7}{|c|}{$\mathrm{ANOVA}^{\mathrm{b}}$} \\
\hline Model & & $\begin{array}{l}\text { Sum of } \\
\text { Squares }\end{array}$ & df & Mean Square & $\mathrm{F}$ & Sig. \\
\hline \multirow[t]{3}{*}{1} & Regresslon & 6509,335 & 1 & 6509,335 & 63,046 &, $000^{\circ}$ \\
\hline & Res/dual & 16209,734 & 157 & 103,247 & & \\
\hline & Total & 22719,069 & 158 & & & \\
\hline
\end{tabular}

a. Predlctors: (Constant). $X 2$

b. Dependent Varlable:Y

\begin{tabular}{|c|c|c|c|c|c|c|}
\hline \multicolumn{7}{|c|}{ Coefficlents ${ }^{\mathrm{a}}$} \\
\hline \multirow{2}{*}{\multicolumn{2}{|c|}{ Model }} & \multicolumn{2}{|c|}{ Unstandardked Coefficlents } & \multirow{2}{*}{ 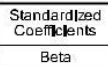 } & \multirow[b]{2}{*}{$t$} & \multirow[b]{2}{*}{ sig. } \\
\hline & & B & Std.Error & & & \\
\hline \multirow[t]{2}{*}{1} & (Constant) & 34,009 & 5,328 & & 6,384 & .000 \\
\hline & $x_{2}$ & .572 & .072 & .535 & 7,940 & ,000 \\
\hline
\end{tabular}

Regression (X1 - X2 - Y) 


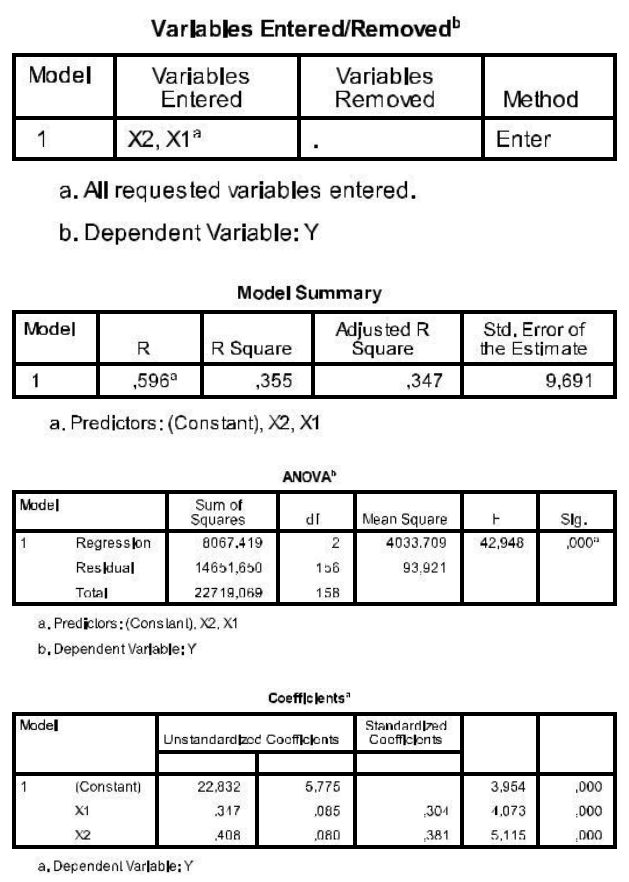

Berdasarkan hasil analisis regresi variabel-variabel penelitian (parsial dan simultan), selanjutnya dijadikan dasar perhitungan analisis jalur dengan langkah-langkah kerja manual sebagai berikut:

\section{Ringkasan Koefisien Model Jalur}

Tabel 2 Ringkasan Koefisien Path

\begin{tabular}{lcccccc}
\hline Struktur & Beta & Koefisien & Notasi & $\mathbf{R}^{2}$ & $1-\mathrm{R}^{2}$ & $\begin{array}{c}\text { Pengaruh } \\
\text { Simultan }\end{array}$ \\
\hline Regresi I & $\mathrm{X} 1$ & 0,304 & $P \mathrm{X} 2 \mathrm{X} 1$ & 0,257 & 0,862 & - \\
\hline Regresi II & $\mathrm{X} 2$ & 0,381 & $P \mathrm{X} 3 \mathrm{X} 2$ & 0,355 & 0,803 & - \\
\hline$\varepsilon$ & - & 0,803 & - & - & - & - \\
\hline $\mathrm{X} 1$ dan X2 & - & - & - & - & - & 0,355 \\
\hline
\end{tabular}

\section{a. Model Jalur Struktur I}

Analisis regresi struktur pertama digunakan untuk menemukan koefisien beta dari hubungan variabel kepemimpinan transformasional (X1) dengan variabel kepuasan kerja (X2). Hasil analisis dengan bantuan program SPSS PASW Statistics 18 memeroleh nilai koefisien beta X1 sebesar 0,506; indeks determinasi ( $\mathrm{R}^{2} / \mathrm{R}_{\text {square }}$ ) sebesar 0,257 ; dan indeks error $\left(\sqrt[1]{-\mathrm{R}^{2}}\right)$ sebesar 0,862 . b. Model Jalur Struktur II

Analisis regresi struktur kedua digunakan untuk menemukan koefisien beta dari hubungan variabel kepemimpinan transformasional (X1) dan variabel kepuasan kerja (X2) dengan perilaku kewargaan organisasi guru (Y). Hasil analisis dengan bantuan program SPSS PASW Statistics 18 memeroleh nilai koefisien beta X1 sebesar 0,304 dan X2 sebesar 0,381; indeks determinasi $\left(\mathrm{R}^{2} / \mathrm{R}_{\text {square }}\right)$ sebesar 0,355 ; dan indeks error $\left(\sqrt{-R^{2}}\right)$ sebesar 0,803. Ringkasan koefisien path disajikan pada Tabel 2.

\section{Ringkasan Signifikansi Koefisien Model Jalur (Beta) dan Uji Signifikansi \\ a. Ringkasan Signifikansi Koefisien Model Jalur (Beta) Adapun ringkasan signifikansi koefisien model jalur}

(beta) dari hasil proses analisis regresi tiap struktur pada Tabel 3.

Tabel 3 Signifikansi tiap Koefisien Path

\begin{tabular}{cccc}
\hline Model Path & Koefisien & Nilai $\mathbf{t}$ & Sign. $\mathbf{t}$ \\
\hline PX2X1 & 0,304 & 7,415 & 0,000 \\
\hline PYX1X2 & 0,381 & 3,954 & 0,000 \\
\hline
\end{tabular}




\section{b. Uji Signifikansi (Uji $t$ dan $U j i F$ )}

Hasil analisis uji $t$ Model Jalur

Struktur I (parsial) dengan

menggunakan taraf signifikansi 0,05

dapat diketahui bahwa nilai signifikansi yang diperoleh sebesar $0,000<0,05$. Hal ini berarti koefisien jalur signifikan. Sehingga dapat disimpulkan bahwa terdapat hubungan yang signifikan antara kepemimpinan transformasional dan kepuasan kerja guru SDN Kecamatan Kras Kabupaten Kediri.

Hasil analisis uji $F$ Model Jalur Struktur II (simultan) dengan menggunakan taraf signifikansi 0,05 dapat diketahui bahwa nilai signifikansi yang diperoleh sebesar $0,000<0,05$. Hal ini berarti koefisien jalur signifikan. Sehingga dapat disimpulkan bahwa terdapat hubungan yang signifikan antara kepemimpinan transformasional dan kepuasan kerja dengan perilaku kewargaan organisasi guru SDN Kecamatan Kras Kabupaten Kediri.

$$
\text { Berdasarkan pengujian }
$$

keseluruhan model jalur secara statistik signifikan, sehingga disimpulkan bahwa variabel eksogen berkontribusi secara simultan dan signifikan terhadap variabel endogen. Model empirik variabel eksogen dan endogen juga signifikan dan memiliki hubungan (Riduwan dan Kuncoro, 2007).

\section{Model Empirik}

Bentuk model empirik hubungan kausal variabel-variabel penelitian seperti diilustrasikan pada Gambar 2.

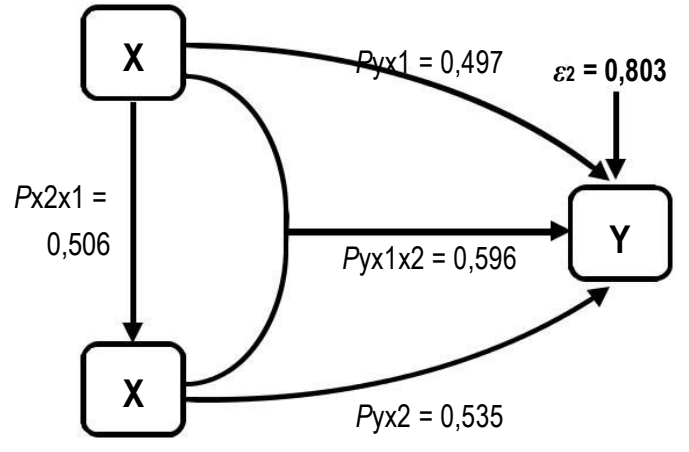

Gambar 2 Model Empirik Hubungan Kausal Variabel

Gambar 2 menunjukkan bahwa koefisien regresi variabel kepuasan kerja $\left(P \mathrm{YX}_{2}=0,535\right)$ lebih besar dari pada koefisien variabel kepemimpinan transformasional $\left(P Y_{1}=0,497\right)$. Sehingga dapat disimpulkan bahwa kepuasan kerja akan meningkatkan perilaku kewargaan organisasi guru dengan dilandasi oleh kepemimpinan transformasional. Kepuasan kerja guru merupakan determinan utama bagi perilaku kewargaan organisasi guru yang dilandasi oleh faktor kepemimpinan transformasional.

\section{Ringkasan Koefisien Hubungan Langsung dan Tidak Langsung} Koefisien hubungan langsung variabel penelitian yakni: $P Y_{1}$ sebesar 0,497; $P \mathrm{YX}_{2}$ sebesar 0,535; dan $P \mathrm{X}_{2} \mathrm{X}_{1}$ sebesar 0,506. Adapun koefisien tidak langsung yakni hubungan tidak langsung $\mathrm{X}_{1}$ dengan $\mathrm{Y}$ melalui $\mathrm{X}_{2}$ sebesar $P \mathrm{X}_{2} \mathrm{X}_{1} . P \mathrm{YX}_{2}=(0,506) \cdot(0,535)=0,271$ (Riduwan dan Kuncoro, 2007:149). Ringkasan koefisien hubungan langsung dan tidak langsung variabel eksogen dan endogen pada Tabel 4. 
Tabel 4 Hubungan Langsung dan Tidak Langsung Variabel

\begin{tabular}{|c|c|c|c|c|c|}
\hline \multirow{2}{*}{$\begin{array}{c}\text { Variabel } \\
\text { Eksogen (X) }\end{array}$} & \multirow{2}{*}{$\begin{array}{c}\text { Koefisien } \\
\text { jalur }\end{array}$} & \multicolumn{3}{|c|}{ Hubungan dengan Variabel Endogen (Y) } & \multirow{2}{*}{$\begin{array}{c}\text { Pengaruh } \\
\text { Simultan }\end{array}$} \\
\hline & & Langsung & Tidak Langsung & Total & \\
\hline $\mathrm{X} 1$ & 0,304 & 0,304 & 0,271 & 0,575 & - \\
\hline $\mathrm{X} 2$ & 0,381 & 0,381 & - & 0,381 & - \\
\hline$\varepsilon$ & 0,803 & - & - & - & - \\
\hline $\mathrm{X} 1$ dan X2 & - & - & - & - & 0,355 \\
\hline
\end{tabular}

Berdasarkan Tabel 4 dapat dijelaskan hasil temuan penelitian bahwa:

a. Variabel kepemimpinan transformasional (X1) memiliki determinasi (sumbangan efektif) terhadap perilaku kewargaan organisasi guru (Y). Dengan demikian tinggi rendahnya perilaku kewargaan organisasi guru dapat dijelaskan oleh kepemimpinan transformasional, secara langsung sebesar 0,304.

b. Variabel kepemimpinan transformasional (X1) memiliki determinasi (sumbangan efektif) terhadap perilaku kewargaan organisasi guru (Y) melalui kepuasan kerja (X2). Dengan demikian tinggi rendahnya perilaku kewargaan organisasi guru dijelaskan oleh kepemimpinan transformasional melalui kepuasan kerja, secara tidak langsung sebesar 0,575.
Hubungan variabel yang terdapat dalam Tabel 4, bilamana koefisien hubungan langsung lebih besar dari koefisien hubungan melalui perantara maka jalur tersebut merupakan jalur yang baik. Akan tetapi bukan berarti koefisien jalur hubungan yang melalui perantara tidak baik, karena hal ini terkait dengan rekomendasi penelitian. Sebaliknya bilamana koefisien jalur hubungan yang melalui perantara lebih besar dari koefisien jalur langsung, maka jalur perantara itulah yang terbaik, dan bukan berarti jalur langsungnya tidak baik.

\section{Indeks Determinasi}

Maksud dari interpretasi indeks determinasi adalah mengungkapkan urutan variabel yang memiliki kontribusi (determinasi efektif) besar terhadap perilaku kewargaan organisasi guru. Untuk menjawab persoalan yang dimaksud, hasil determinasi analisis jalur berdasar pengolahan data pada Tabel 5 .

Tabel 5 Indeks Determinasi tiap Variabel Eksogen terhadap Endogen

\begin{tabular}{ccccc}
\hline Variabel & Beta & ryxi & Determinasi (efektif) & Pengaruh Simultan \\
\hline $\mathrm{X} 1$ & 0,304 & 0,497 & 0,151 & - \\
\hline $\mathrm{X} 2$ & 0,381 & 0,535 & 0,204 & - \\
\hline $\mathrm{X} 1$ dan X2 & - & - & - & 0,355 \\
\hline
\end{tabular}


Berpedoman pada Tabel 5 dapat dijelaskan bahwa indeks determinasi (sumbangan efektif) terhadap perilaku kewargaan organisasi guru (Y) adalah kepemimpinan transformasional (X1) sebesar $15,1 \%$ dan kepuasan kerja guru (X2) sebesar 20,4\%. Indeks determinasi variabel eksogen secara simultan memengaruhi variabel endogen sebesar $35,5 \%$ dan sisanya sebesar $\varepsilon^{2} \cdot 100 \%=(0,803)^{2}$ $.100 \%=0,645$

. $100 \%=64,5 \%$ (Riduwan dan Kuncoro, 2007:149) merupakan kontribusi variabel lain di luar penelitian ini. Perhitungan indeks determinasi (sumbangan efektif) variabel penelitian diinterpretasi kan pada Gambar 3.

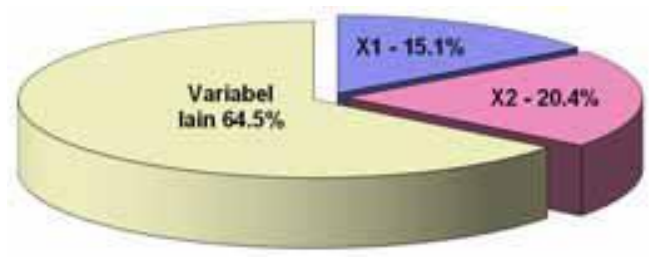
Gambar 3 Diagram
Persentase
Sumbangan Efektif Variabel Penelitian (X1 dan X2) dan Variabel Lain terhadap Variabel Y

\section{Pembahasan}

Berdasarkan hasil penelitian terdapat pengaruh yang signifikan kepemimpinan transformasional dan kepuasan kerja terhadap perilaku kewargaan organisasi guru SDN Kecamatan Kras Kabupaten Kediri. Indeks determinasi (sumbangan efektif) terhadap perilaku kewargaan organisasi guru (Y) adalah kepemimpinan transformasional (X1) sebesar 15,1\%; kepuasan kerja guru (X2) sebesar 20,4\%; dan variabel lain di luar variabel penelitian sebesar $64,5 \%$ seperti komitmen organisasi, kepribadian guru, dan lama bekerja guru. Pemimpin transformasional merupakan pemimpin yang karismatik dan mempunyai peran sentral dan strategis dalam membawa organisasi mencapai tujuannya. Pemimpin transformasional juga harus mempunyai kemampuan untuk menyamakan visi masa depan dengan bawahannya, serta mempertinggi kebutuhan bawahan pada tingkat yang lebih tinggi dari pada apa yang mereka butuhkan. Hal ini sesuai dengan pendapat Hasibuan (2007) yang menyatakan salah satu faktor yang memengaruhi kepuasan kerja guru ialah sikap pimpinan dalam kepemimpinannya.

Kepemimpinan kepala sekolah merupakan kunci keberhasilan sekolah. Kesempatan untuk mengembangkan sebuah sekolah hingga menjadi sebuah sekolah yang sungguh efektif kiranya membutuhkan kreativitas kepemimpinan yang memadai. Kreativitas kepemimpinan semacam itu dapat terlihat atau dapat muncul manakala para pimpinan sekolah mampu dan mau melakukan perubahanperubahan tentang cara dan metode yang mereka pergunakan untuk mengelola sekolah. Kemampuan serta kemauan tersebut akan muncul manakala para pimpinan sekolah dapat membuka diri secara luas untuk mencari dan menyerap sumber-sumber yang dapat mendorong perubahan 
manajerial, dan kiranya konsepkonsep dasar untuk melakukan perubahan tersebut tersedia luas dalam bidang di luar bidang pendidikan itu sendiri.

Kepemimpinan

transformasional menyangkut

bagaimana mendorong orang lain

untuk berkembang dan

menghasilkan performa melebihi

standar yang diharapkan. Pimpinan

yang memiliki gaya

transformasional mampu

menginspirasi orang lain untuk

melihat masa depan dengan

optimis, memproyeksikan visi

yang ideal, dan mampu

mengomunikasikan bahwa visi

tersebut dapat dicapai. Para

pimpinan transformasional lebih

mampu dan lebih sensitif

merasakan lingkungannya, dan

untuk selanjutnya membentuk dan

mendiseminasi sasaran-sasaran

strategis yang mampu menangkap

perhatian serta minat para gurunya.

Kebanyakan peneliti mengevaluasi keefektifan kepemimpinan dalam

kaitannya dengan konsekuensi-

konsekuensi dari tindakan-

tindakan pemimpin tersebut bagi

para pengikut dan para stakeholder

organisasi lainnya. Ukuran yang

biasanya digunakan mengenai

keefektifan pemimpin adalah

sejauh mana unit organisasi dari

pemimpin tersebut melaksanakan

tugasnya secara berhasil dan

mencapai tujuan-tujuannya.

Indikator umum lainnya adalah sikap dari para pengikut terhadap pemimpin tersebut, seperti rasa suka, puas, hormat, dan kagum kepada pemimpinnya serta ada tidaknya komitmen yang kuat untuk melaksanakan permintaanpermintaan dari pemimpin.

Keberhasilan mewujudkan kepuasan kerja guru juga ditentukan oleh gaya kepemimpinan yang diterapkan oleh kepala sekolah. Tujuan kepuasan kerja guru adalah agar guru dapat memandang pekerjaan sebagai suatu hal yang menyenangkan. Sehingga jika guru senang dalam bekerja serta senang terhadap pekerjaannya, maka diharapkan siswa juga senang dalam belajar dan akhirnya ini bisa meningkatkan prestasinya. Hal ini didukung oleh hasil penelitian Brahmasari dan Suprayetno (2008:133) yang menyimpulkan bahwa ada pengaruh yang signifikan kepemimpinan terhadap kepuasan kerja karyawan. Sehingga apa yang dilakukan oleh kepala sekolah diharapkan dapat meningkatkan kemampuan dan kepuasan kerja guru. Kepuasan kerja guru menjadi sangat penting, untuk meningkatkan produktivitas guru.

Kepuasan kerja adalah bagian dari kepuasan hidup. Sifat lingkungan seseorang di luar pekerjaan mempengaruhi perasaan di dalam pekerjaan. Demikian juga halnya pekerjaan, karena merupakan bagian penting kehidupan, kepuasan kerja mempengaruhi kepuasan hidup seseorang. Sehingga dapat disimpulkan bahwa kepuasan kerja merupakan kunci pendorong moral, kedisiplinan, dan prestasi kerja guru dalam mendukung 
terwujudnya tujuan pendidikan. Kepuasan kerja guru adalah perasaan guru tentang menyenangkan atau tidak mengenai pekerjaan berdasarkan atas harapan guru dengan imbalan yang diberikan oleh sekolah. Bertolak dari pemahaman di atas, pihak sekolah dituntut untuk secara bertahap dan terus menerus memenuhi seluruh kebutuhan pegawai agar kepuasan pegawai dapat diwujudkan di tempat kerjanya karena kepuasan pegawai akan berdampak langsung terhadap kinerjanya. Kepuasan kerja guru penting untuk aktualisasi diri. Guru yang tidak memperoleh kepuasan kerja tidak akan pernah untuk mencapai kematangan psikologis dan akan menjadi frustrasi, sehingga dapat menyebabkan guru akan senang melamun, mempunyai semangat kerja rendah, cepat lelah atau bosan, emosi tidak stabil, sering absen, dan mengakibatkan turunnya kinerja guru. Oleh karena itu, kepuasan kerja mempunyai arti yang penting, baik bagi guru maupun sekolah terutama karena menciptakan keadaan positif dalam lingkungan kerja.

Pegawai yang memiliki perilaku kewargaan organisasi rendah memiliki kecenderungan untuk meninggalkan organisasi (keluar) dibandingkan dengan karyawan yang memiliki tingkat perilaku kewargaan organisasi tinggi. Hal ini sesuai dengan penelitian George yang menyimpulkan adanya perilaku altruistic memungkinkan sebuah kelompok bekerja secara kompak dan efektif untuk saling menutupi kelemahan masing-masing (LaMastro, 1999). Greenberg dan Baron (2000) menyatakan bahwa karyawan atau anggota organisasi dengan komitmen yang tinggi akan memiliki loyalitas yang tinggi pada organisasi sehingga akan memunculkan perilaku bersedia berkorban demi kepentingan organisasi. Perilaku kewargaan organisasi sebagai suatu perilaku yang bersifat sukarela dan tanpa adanya sistem reward secara langsung terbentuk dan muncul karena dipengaruhi oleh banyak faktor.

\section{E. Simpulan dan Saran}

Bertolak dari hasil penelitian dan pembahasan, dapat dikemukakan simpulan penelitian ini, adalah: (1) terdapat pengaruh yang signifikan kepemimpinan transformasional terhadap perilaku kewargaan organisasi guru; (2) terdapat pengaruh yang signifikan kepuasan kerja terhadap perilaku kewargaan organisasi guru; dan (3) terdapat pengaruh yang signifikan kepemimpinan transformasional dan kepuasan kerja terhadap terhadap perilaku kewargaan organisasi guru SDN Kecamatan Kras Kabupaten Kediri.

Berdasarkan simpulan penelitian, saran yang diajukan ialah kepada para guru SDN Kecamatan Kras Kabupaten Kediri hendaknya selalu ingin melakukan pekerjaan melebihi apa yang telah disyaratkan dalam uraian pekerjaan, selalu mendukung visi, misi, dan tujuan sekolah. Hal ini dapat dilakukan dengan 
membuat sistem komunikasi berupa sistem group sosial media dan konsolidasi berjangka antarguru sehingga dapat menyampaikan saran dan pendapatnya bagi kemajuan sekolah. Kepada Kepala SDN Kecamatan Kras Kabupaten Kediri hendaknya menerapkan kepemimpinan transformasional dengan memerhatikan situasi yang dihadapi di sekolah. Agar kepemimpinan yang diterapkan tepat bagi bawahannya, hendaknya kepala sekolah memahami karakteristik para gurunya.

$$
\text { Kepada Pengawas SDN }
$$

Kecamatan Kras Kabupaten Kediri hendaknya juga menerapkan kepemimpinan dalam konteks supervisi pengajaran. Pengawas dapat meningkatkan kepuasan kerja dan perilaku kewargaan organisasi guru dengan menerapkan pendekatan supervisi pengajaran yang berorientasi pada psikologi humanistik. Guru diberi kesempatan untuk menilai diri sendiri terhadap pembelajaran yang dilaksanakannya. Kepada peneliti lain hendaknya memperhatikan hasil penelitian ini untuk dikembangkan lebih lanjut melalui penelitian yang lain dengan menggunakan variabel, responden, teknik penelitian yang berbeda, dan ruang lingkup yang lebih luas sehingga dapat berdampak lebih baik bagi perilaku kewargaan organisasi guru.

\section{DAFTAR RUJUKAN}

Arikunto, S. 2010. Prosedur Penelitian: Suatu Pendekatan Praktik. Jakarta: PT Rineka Cipta.

Bass, B. M . 1985. Leadership and Performance Beyond Expectation. New York: The Free Press.

Boje, D. M. 2000. Transformational Leadership, (Online). (http://business. nmsu.edu/ dboje/teaching/338/tra nsformational_leadership.htm, diakses 24 Juni 2009).

Borman, W., dan Motowidlo, S. 1993. Personal Selection in Organization. San Franscisco: Jossey-Bass.

Brahmasari, I. A., dan Suprayetno, A. 2008. Pengaruh Motivasi Kerja, Kepemimpinan, dan Budaya Organisasi terhadap Kepuasan Kerja Karyawan serta Dampaknya pada Kinerja Perusahaan (Studi kasus pada PT Pei Hai International Wiratama Indonesia). Jurnal Manajemen dan Kewirausahaan, 10(2): 124-135.

Burns, J. M. 1978. Leadership. New York: Harper dan Row Publishers.

Davis, K., dan Newstroom, W. J. 2002. Behavior in Organization. New York: Pearson.

Draper, N. R. dan Smith, H. 1998. Applied Regression Analysis. New York: Wiley.

Greenberg, J., dan Baron, R. 2000. Behaviour in Organizations: Understanding and Managing the Human Side of Work. New Jersey: Prentice hall. 
Handoko, T. H. 1999. Manajemen. Yogyakarta: BPFE.

Hasibuan, M. S. P. 2007. Manajemen Sumber Daya Manusia. Jakarta: PT Bumi Aksara.

Kusmintardjo. 1989. Kepemimpinan dalam Pendidikan. Dalam Soekarto, I., dan Soetopo, H., (Eds.), Administrasi Pendidikan (hlm. 251-279). Malang: Penerbit IKIP Malang.

LaMastro, V. 1999. Commitment and Perceived Organizational Support. National Forum of Applied Educational Research Journal, 12(3): 113.

Organ, D. W. 1988. Organizational Citizenship Behavior: The Good Soldier Syndrome. Lexington, MA: Lexington Books.

Podsakoff, P., Ahaerna, M., dan Mackenzie, S. 1997. Organitational Citizenship Behaviour and Quantity and Quality of Work Group Performance. Journal of Applied Psychology, 2(1): 262-270.

Prihatsanti, U., dan Dewi, K. S. 2010. Hubungan antara Iklim Organisasi dan Organitational Citizhensip Behaviour pada Guru SD Negeri di Kecamatan
Mojolaban Sukuharjo. Jurnal Psikologi Universitas Diponegoro, 7(1): 11-16.

Riduwan, dan Kuncoro, E. A. 2007. Cara Menggunakan dan Memaknai Analisis Jalur (Path Analysis). Bandung: Alfabeta.

Riggio, R. 2003. Introduction to Industrial Organizational Psychology. New York: Prentice Hall.

Robbins, S. P. 2003. Organizational Behavior. New Jersey: Pearson Education International.

Teresa, N., dan Suyasa, P. Y. 2008. Komitmen Organisasi dan Organitational Citizenship Behaviour pada Karyawan Call Center PT X Phronesis. Jurnal Psikologi Industri dan Organisasi, 10(1): 154-169.

Wexley, K. N., dan Yulk, G. 1977.

Organizational Behavior and Personnel Psychology. New York: R. D. Irwin.

Winarsunu, T. 2002. Statistik dalam Penelitian Psikologi dan Pendidikan. Malang: UMM Press.

Wiyono, B. B. 2004. Metode Penelitian Kuantitatif. Malang: Program SP4 Jurusan Administrasi Pendidikan Fakultas Ilmu Pendidikan Universitas Negeri Malang.

Yukl, G. 2009. Leadership in Organizations. New Delhi: Dorling Kindersle 
